\title{
Migration, Transnationalism and the Shaping of Zimbabwean Pentecostal Spirituality*
}

\author{
Kudzai Biri \\ Department of Religious Studies Classics and Philosophy, \\ University of Zimbabwe, Mount Pleasant, Harare, Zimbabwe \\ kudzibiri@gmail.com
}

\begin{abstract}
This article explores the effects of global expansion and the importance of diasporic transnational connections on the theology and practice of an African Pentecostal church. It takes the case of Zimbabwe Assemblies of God Africa (ZAOGA), one of the largest and oldest Pentecostal churches in Zimbabwe. The growth of this Pentecostal movement, both within and without Zimbabwe, has depended centrally on the homeland church leadership's capacity to maintain transnational connections with its own external congregations, termed Forward in Faith Ministries International (FIFMI). The article examines how transnational ties, strengthened through the phenomenal exodus from Zimbabwe from 2000 and the associated creation of new diasporic communities, have affected the church's teaching and practice. Existing literature on globalised African Pentecostal movements elaborates how these churches can provide modes of coping, cutting across geographical and conceptual boundaries to create powerful new transnational notions of community that enable congregants to cope with circumstances of rapid change, uncertainty and spatial mobility. Here, I argue that zAOGA's teaching encouraged emigration over the period of the Zimbabwe crisis, but combined this with an emphasis on departure as a temporary sojourn, stressed the morality and importance of investing in the homeland, and promoted a theology of Zimbabwe as morally superior to the foreign countries where diasporic communities have grown up. A sense of transnational Pentecostal religious community has thus developed alongside the circulation of essentialised notions of national cultural difference hinging on derogatory stereotypes of foreigners while elevating the moral supremacy of Zimbabwean nationhood.
\end{abstract}

\footnotetext{
* This research was funded by ESRC research grant number RES ooo 22 3795. It builds on the authors $\mathrm{PhD}$ research.

(C) KUDZAI BIRI, $2014 \mid$ DOI: 10.1163/18725465-00701007

This is an open access article distributed under the terms of the Creative Commons 


\section{Keywords}

religion - diaspora - transnationalism - Pentecostalism - Zimbabwe

\section{Résumé}

Cet article explore les effets de l' expansion mondiale et de l'importance des connexions diasporiques sur la théologie et les pratiques de l'Église pentecôtiste africaine. Il prend l'exemple des Assemblées de Dieu Afrique du Zimbabwe (Zimbabwe Assemblies of God Africa - ZAOGA), une des plus grandes églises pentecôtistes de ce pays. L'expansion de ce mouvement pentecôtiste à la fois au Zimbabwe et à l'étranger a dépendu principalement de la capacité de leadership de l'église dans ce pays à maintenir des connexions transnationales avec ses propres congrégations intitulées Ministères Internationaux des Avancées de la Foi (Forward in Faith Ministries International - FIFMI). L' article examine la manière dont les liens transnationaux, renforcés par l'exode massif des Zimbabwéens à partir de 2000 et par la création de nouvelles communautés diasporiques, a affecté les enseignements et les pratiques de l'église. La littérature consacrée aux mouvements pentecôtistes africains mondialisés ont démontré comment ces églises proposaient des solutions pour faire face en court-circuitant les frontières géographiques et conceptuelles afin de créer de nouvelles notions de communautés transnationales particulièrement puissantes qui permettaient aux adeptes de faire face aux changements rapides, aux incertitudes et à la mobilité spatiale. Dans cet article, je défends l'idée que les enseignements des ZAOGA ont encouragé l'émigration pendant la crise qu' a connue le Zimbabwe mais en insistant sur le fait que l' exil devait être temporaire, sur la moralité et sur l'importance d'investir dans le pays d' origine et en promouvant une théologie du Zimbabwe comme étant supérieur aux autres pays où les communautés diasporiques ont grandi. Le sens d'une communauté religieuse pentecôtiste transnationale s' est ainsi développée parallèlement à aux notions essentialisées des différences culturelles nationales, celles-ci flirtant souvent avec des préjugés négatifs au sujet des étrangers et affirmant la supériorité morale de l'identité nationale zimbabwéenne.

\section{Mots-clés}

religion - diaspora - transnationalisme - pentecôtisme - Zimbabwe 


\section{Religious Transnationalism}

Religion has increasingly been viewed as a transnational phenomenon (Levitt 1998; Pasura 2012; Wuthnow and Offutt 2008). As Wuthnow and Offutt (2008: 209) explain, although religion "exists in local communities and is distinctively influenced by a national cultural and political context, it has connections with the wider world and is influenced by these relations". This expanding interest in religious transnationalism has begun to rectify the prior neglect within religious studies of the effects of migration on faith communities. Hinnells (1997) noted that earlier on scholars of migration had overlooked religion just as scholars of religion had overlooked migration. But the now voluminous literature on migrants' transnational economic, cultural and social connections has now also expanded to make connections with scholarship on religion (Levitt 1998, 2008; Mahler and Hansing 2005; Fumanti 2010; Pasura 2012; Pasura 2014), with rich bodies of research on religious dimensions of incorporation in American contexts (Levitt 1998; Levitt 2008; Mahler and Hansing 2005; Menjivar 1999), global Pentecostalism and Islamic transnationalism in Europe (Ter Haar 1998; Dijk 1997; Hunt 2002; Ralph 2004).

It is the scholarship on African Pentecostal churches that is particularly relevant here (Gifford 2004; Anderson 2004). The dramatic expansion of these churches has been described not only as a profound 'reformation of African Christianity' (Anderson 2004: 5), but also as transforming the religious landscapes of European and other global contexts where African migrants have taken their faith. Authors explain the attractions of these churches and the modes of subjectivity they construct through their capacity to provide a means of coping with rapid socio-economic change, urbanisation, neo-liberalism and globalisation. As van Dijk (1997: 140) explains, the growth of Pentecostalism should "be understood primarily in terms of the differentiated responses it is able to offer to local attempts of coming to grips with wider national and international processes and contexts of global capitalism and state formation". In Southern Africa, the 'durawall' ${ }^{1}$ of Pentecostal faith has proved attractive to populations facing uncertainty and engaged in new forms of mobility (Maxwell 2006a). This metaphor aptly captures not only aspirations to achieve wealth, but also the boundary-drawing capacity of faith: how Pentecostal churches can offer a source of physical and symbolic protection for personal space against hostile external forces. The forms of community that these churches provide

1 The word 'durawall' refers to the concrete walling surrounding a property such as a suburban home (Maxwell 2006a: 187). 
can underpin a growing individualism as well as a quest for economic advancement, hinging on a conceptual 'break with the past' and repudiation of 'tradition' (Maxwell 1998; Meyer 1998). Within transnational diasporic contexts, the 'reverse missionization' (Maxwell 2006b, 392) promoted through Pentecostal and other African Christian churches has given African migrants a sense of purpose, belonging and moral strength in European contexts that can be hostile and exclusionary, supporting drives to evangelise what are cast as decadent old imperial centres and rejuvenating dwindling congregations (Fumanti 2010; Maxwell 2006a; Pasura 2012; Adogame 2009; Koning 2009; Ter Haar 1998; Catto 2008).

This rejuvenation of Christianity in Europe by African diaspora and other transmigrant congregations through a 'reverse flow' (Kalu 2008: 270) and 'reverse proselytization' (Hung 2002:165) from the global south has attracted a significant scholarship. Koning's study (2009) of Ghanaian Adventists in Amsterdam identifies three usages of the term reverse mission. The first usage relates to "the sheer presence of these [African] churches" and "numerical enlargement of Christians in Europe". The second sense refers to "the modelling of a specific kind of Christianity that European Christians have neglected, i.e. a holistic type combining spirituality with social engagement" (Koning 2009: 204). The third sense describes "the specific intentions and actions of African Christians to reach out to the European 'natives' amongst whom they live" (Koning 2009, 204). These last two senses are key - i.e. the combination of social support and external mission - with the latter being particularly important in terms of the churches' own presentation of themselves, such that diaspora churches in Adogame's terms "define and understand themselves not so much by migration but by mission" (Adogame 2008: 311; see also Catto 2008; Koning 2009, 205; Ter Haar 1998).

This sense of global mission and membership within the sacred body of a Pentecostal transnational community, however, can sit uneasily with Levitt (2008) and others' emphasis on civic values and global citizenship if these are to be equated with ideas of liberalism. As Marshall argued, beyond the democratic access to personal spiritual power, or the quest for a pacified and ordered political realm built through Christian obedience, "the perpetual engagement with the figure of the demonic shows the anti-democratic side of Pentecostalism" (Marshall 2009:14). She continues:

The ambivalence and excess of meaning of the "sacred" creates the need to interpret the demonic not only in terms of individual moral failures, but also as part of a global struggle between forces of good and evil. This provides the grounds for the violent assertion of identity through the 
images of spiritual warfare that extends outward from the individual soul to the entire globe: at the heart of salvation, an ongoing and permanent engagement with the demonic.

MARSHALL-FRATANI 2009: 14

In the Nigerian context, Marshall explores how the struggle between Pentecostalism and Islam has been extremely violent, while intolerance on the continent has also been expressed in violent denunciations of homosexuality, ethnic chauvinism and acquiescence to, or active support for authoritarian, repressive regimes, as in the Zimbabwean case explored below (Maxwell 2006a; Chitando 2005). The notion of 'break with tradition' as it is fostered through some churches has reinvented ideas about witchcraft and evil, producing new movements against child witches as the embodiment of Satanic forces (Englund 2007).

The crisis period in Zimbabwe from 2000 was one in which Pentecostal churches continued to grow - both across Zimbabwe and in diasporic communities. But authors have not fully explored how the transnational connections strengthened over the crisis years shaped changing Pentecostal landscapes. Maxwell's (2006a) study offered insights into the earlier transnational spread of ZAOGA through the neo-liberal reforms and economic decline of the 1990s. Here, we focus on the subsequent decade of mass emigration. Studies of the Zimbabwean exodus and impact of new diasporic communities on the homeland are strongest in their attention to political, economic and social consequences (Crush and Tevera 2010; McGregor and Primorac 2010). Initially, there was a notable gap in this literature on the role of churches and faith (McGregor and Primorac 2010). The exceptions are Pasura's (2012; 2013) recent work on Zimbabwean diaspora congregations' role in maintaining transnational ties and shaping integration in Britain and Maxwell's (2006a) study of ZAOGA diasporic communities in the 1990s. Mobility and religion are connected in different ways, not only through new social dynamics in global host lands, but because new diasporic communities are affecting religious messages and beliefs in the homeland as well. Pentecostal churches are transnational conduits shaped through migration and multiple cross-border influences, accentuating the point that "the flow of people, money, and 'social remittances' (ideas, norms, practices, and identities) within these spaces is so dense, thick, and widespread that non-migrants' lives are also transformed, even though they do not move" (Levitt and Jaworsky 2007: 132).

Using ZAOGA and its external missions, Forward in Faith Ministries International (FIFMI) as a case study, the article examines how transnational connections, strengthened through the phenomenal exodus of Zimbabweans and 
new diasporic communities, have affected the church's teaching and practice. It examines how Zimbabwean Pentecostal Christians belonging to this transnational church make sense of emigration, and how they construct transnational life worlds around their faith and church messages, focusing on the impact of ZAOGA's increasing global reach on homeland faith communities. ZAOGA started in the 1960s as a predominantly urban movement in Harare's Highfields Township, which was also the birthplace of Zimbabwean nationalism. As Maxwell (2001: 520) argues, the production of sacred texts by ZAOGA helped consolidate and authorise a transnational Pentecostal movement, "enabling ZAOGA to make a universal transition from an urban-based sect with strong links to Christian independency into a modern international denomination". ZAOGA is one of the largest Pentecostal churches in Zimbabwe and FIFMI claims to be well established in over 104 countries, including the UK, USA, Australia, Ukraine, Malaysia and China as well as proximate southern African countries. ${ }^{2}$ In the various geographical locations where FIFMI has flourished, the church consistently raises the spiritual profile of Ezekiel Guti, its Zimbabwean founder. To do so, the church has depended increasingly on new media technologies that also strengthen transnational ties and create the sense of belonging to an integrated scared global institution rooted in a central Zimbabwean homeland.

The formation of diasporic communities across the globe has helped to raise the international profile of the church and has given it economic and social 'stamina' amidst multiple crises at home. At the same time, ZAOGA has managed to maintain Zimbabwe as the original spiritual centre. The church's global spread has not gone unchallenged either at home or abroad, and although ZAOGA/FIFMI has expanded dramatically, it has also faced increasingly serious opposition from newly formed rival Pentecostal denominations in the diaspora as well as in Zimbabwe. At the 2010 Deeper Life Conference, for example, Guti berated his pastors for losing members to Makandiwa's ${ }^{3}$ United Families International, particularly in the diaspora. Other Pentecostals with well-established diasporic churches that compete with ZAOGA/FIFMI include Prophet тв Joshua's Synagogue Church of All Nations (sCOAN), a globalised Nigerian Pentecostal movement.

The article is based on formal and informal interviews with ZAOGA pastors and church members as well as participatory observation of ZAOGA services

2 http://www.fifmi.org [accessed March 2013]. These claims may be exaggerated, and require verification by future research.

3 Emmanuel Makandiwa is an ex-Apostolic Faith Mission pastor and founder of United Family Interdenominational Ministries, one of the biggest Pentecostal churches in Zimbabwe at present. 
and other events. In the wake of past critical writing on the church by scholars (Maxwell 2006a), ZAOGA leadership does not welcome researchers. The author has the advantage of a long history of membership of ZAOGA in Zimbabwe, however, so draws on testimonies and teachings/sermons in church services I have attended over the last few years. Interviewees include people with personal experience of ZAOGA/FIFMI diaspora communities as well as those whose only understanding of the transnational reach of the church is through what they have heard at home. ${ }^{4}$

Below, I explore ZAOGA leader Ezekiel Guti's own religious trajectory outside Zimbabwe and the way it has been incorporated into ZAOGA theology. It then examines how foreign places hosting Zimbabwean diaspora communities are represented within church teaching at home. Finally, the article investigates some of the mechanisms the church uses to foster transnational connections, including diasporic pilgrimages to Guti's home in Highfield, Zimbabwe, deliverance crusades known as 'Explos' and the church's own TV channel.

\section{The Life and Experiences of Ezekiel Guti in Dallas}

The narration of Dr Ezekiel Guti's life and experiences from his rural home in Chipinge through his time of education in the United States and return home are a central aspect of ZAOGA's theology and teachings (Maxwell 2001, 2006a). For ZAOGA members in the diaspora, Guti's Dallas sojourn has become a key frame of reference for understanding their experiences abroad. For those remaining within Zimbabwe, it also provides a context for understanding emigration and diasporic identifications that hinge on obligations to, connections with, and influence at home.

In 1972, Guti went to Christ for Nations College in Dallas, the USA, for his pastoral studies (Maxwell 2006a). Soon after completing his studies, Guti claims, God told him to go back to Zimbabwe because "there is a lot of money" (Guti 1997: 46). The church's religious narrative tells of how he was commanded to teach his followers to work hard to achieve God's blessing and that they should learn to give and tithe. "(...) Go and teach my word, teach my people to give and tithes and also to work talents and I will bless them" (Guti 1997: 46). In this

4 This research furthered my DPhil research on ZAOGA: the topics (and findings of this bigger project) were not considered controversial or sensitive, and my writings have been deposited at the Zimbabwe Ezekiel Guti University in Bindura. The interviewees spoke to me with knowledge of my DPhil research and writing: those quoted in this article gave informed consent to be cited by name. 
way, members of the church will become rich. The authenticity of this account is not questioned within ZAOGA; rather it is an intrinsic part of the church's founding narrative and deification of its leader. Church members strive to obey the decrees of Dr Guti, the 'man of God', by making themselves subservient, as the church cultivates total allegiance and discourages any questioning of leaders' decisions and decrees. Rather than questioning the truth-value of church claims, it is thus necessary to examine how such claims have influenced ZAOGA theology and praxis. As van Dijk (2002: 50) tells us, "many of the new Pentecostal churches appear to pursue a gospel of individual prosperity, emphasise private enterprise writ large, seek personal redemption, pursue business interests and certainly venerate their influential leaders in a kind of personality cult". Below, I explore how the narrative of Guti's personal sojourn abroad shapes ZAOGA's political theology of mobility, work and wealth, as well as church members' own decisions, the meanings they give to migration and the development of diasporic communities.

\section{The School of Talents and the Theology of Investment at Home}

Guti returned to Zimbabwe spiritually 'equipped' to teach his people that God promised them wealth if they give and tithe and that they should work hard. These messages derived from his sojourn abroad have been incorporated into church theology on mission and international mobility, particularly through the ideas underpinning the School of Talents, which is central to teachings on work, tithing and investment (see also Maxwell 1998, 2006a). The concept of Talents, first initiated by Priscilla Ngoma, one of the School's co-founders, was borrowed from the biblical book of Matthew 25:14-30. Although everyone is encouraged to develop Talents in ZAOGA, this aspect of the church's teaching is specifically targeted at women. ZAOGA discourages idleness and the 'folding of hands' (Gifford 1988:68) and through Talents women are encouraged to venture into business to empower themselves. Talents are referred to as a 'School' because members have to be taught the art and moral duty of hardworking. The proceeds from the Talents can either be used for personal use (Home Talents) or given to the church.

ZAOGA and FIFMI communities both raise money for the church, and it is not always clear exactly where wealth originates, for example, to fund missions or the generous 'Birthday Gifts' for the leadership, or the large-scale developmental projects ZAOGA has embarked upon in Zimbabwe. Maxwell (2006a) discusses how transnational activities are key to church fundraising, elaborating how sacred history gives theological coherence and underpins church identity. 
Over the past decade it is clear that diasporic sources have increased in importance, and the church continues to use the theology of Talents to influence migration, accumulation and investment from diasporic sources. According to Guti, going to the diaspora promotes 'tent-making' (Guti 2010). This metaphor invokes the Apostle Paul and is used to foster missionary work, but it also has a wider set of meanings and values associated with temporariness, mobility, hard work and sacrifice for the church. Using the biblical life of the Apostle Paul, ZAOGA members living abroad are encouraged to start bible study groups. Most ZAOGA churches outside Zimbabwe were started as home cells pioneered by those who sought work outside the country. When the cell size increases, a pastor is sent by ZAOGA headquarters, usually appointed directly by Guti himself to register and 'bless' the church (Maxwell 2006a: 167). This is a way of 'stamping' and extending central authority, attempting to prevent the breakaways that characterise Pentecostal movements, including ZAOGA itself.

Tangible evidence of the success of Talents at home and abroad is provided by their new material manifestations such as the ZAOGA hospital (Mbuya Dorcas Hospital, named after Guti's mother) that was built in 2008 in Harare's Waterfalls suburb and Ezekiel Guti University in Bindura (which opened in 2012 but is still under construction). ZAOGA built a number of schools and preschools across Zimbabwe over the duration of the crisis years. Interviewees living abroad stressed their own contributions to these projects as an important expression of their faith and commitment to home. As a Zimbabwean ZAOGA member living in Tanzania explained to me in Harare:

Decrees by Baba are communicated in every church. We have been contributing money towards the hospital, Baba's love offering and all the items that were called for, we participated ... we are doing the same [giving and tithing], even while we are far away. ${ }^{5}$

A PhD student in Pretoria also underlined his tithing and gifts "for Baba's birthday, for the church in Bindura and Ezekiel Tv". ${ }^{6}$ In Botswana in 2010, the FIFMI community invited Guti and his wife Eunor to witness and 'bless' the work of their hands by buying special peanut butter (dovi). Those who bought the symbolic bottles of peanut butter for US $\$ 200$ claimed miracles resulted from it. A bottle of dovi usually costs a dollar but because Eunor had prayed for the bottles, they were anointed, and members were encouraged to store

5 Interview, Ezekiel Mtetwa, 27/07/2011.

6 Interview, Sylvester Mawere, 10/02/12. 
them in their houses or business premises. The funds generated through this miraculous dovi initiative in Botswana allowed the church to purchase 79 new houses and several cars. ${ }^{7}$

The church has multiple theological explanations for how it accumulated wealth during Zimbabwe's economic and political crisis. In Harare, for instance, many female cross-border traders testified during women's meetings as to how they were able to fund the church during the peak of the economic crises (pers. obs), and interviewees who worked in the region also strove to emphasise how much they had contributed. ${ }^{8}$ For these women, financial gifts to the church showed that God is not bound by the economic crisis, and their sacrifice of money was also witness to their faith in Guti: Regina Zivuku, a Deaconess working in South Africa stressed, "it is we [Zimbabwean members of FIFMI in the diaspora] who were the ones supporting Amai [Eleanor Guti] at home with our gifts, participating in the hospital and other projects". ${ }^{\text {ZAOGA uses analo- }}$ gies of 'sowing' and 'reaping' to make the church attractive, and can exert pressure on members to give in this way. Members hope to get rich miraculously because they have obeyed the teachings of Guti. Other Pentecostal denominations have now emulated ZAOGA teaching on Talents. ${ }^{10}$

Drawing from the example of Guti's own temporary sojourn in Dallas, the migration of Zimbabweans abroad is constructed as temporary and an opportunity to invest at home as well as to proselytise. The church regularly condemns those accumulating assets abroad who are not investing at home and urges migrants to send and invest the products of their labour in Zimbabwe. Leaders use the tangible evidence of diaspora wealth as a way of berating those whose help at home is insufficient and to encourage those left behind to work hard. Preaching to home congregations, Guti has been critical of those who left for failing to remember those within Zimbabwe and lessen their suffering, while at the same time, using the threat of the abundance of returning diasporans to stimulate those at home to work hard. ${ }^{11}$ Guti argues that if they do not, returnees will come back home with money and acquire land and property because the diaspora is not a permanent home. Indeed, Guti and his pastors claim that the situation in the diaspora will be bad and many Zimbabweans will come back home. As ZAOGA Pastor Jeff Gadzika explains,

\footnotetext{
7 Interview Pastor Gadzika, 26/o6/2011.

8 E.g. interview Regina Zivuku 6/07/11.

9 Interview, Regina Zivuku, 6/07/11.

10 Immanuel Makandiwa, on Zimbabwe TV, 15/01/12.

11 Personal observation, sermons in Harare.
} 
Our father Ezekiel has always told us that things will be bad in the diaspora and many will flock back home. I had a revelation of this. So we should work and invest here rather than spend many years out there toiling and coming back home with nothing. Going out is good because most of our FIF churches were started by people who were posted out of the country at their workplaces. So it depends: going out is not really bad, but have an aim and know where you belong. We condemn the violence that accompanied the grabbing of land, but God knows the land is our birthright. Those who have gone to the foreign land will come back because it will not be well with them forever. ${ }^{12}$

Guti encouraged church members to participate in Mugabe's controversial exercise to seize and redistribute white commercial farmland (Chitando 2005). Guti also provided theological and moral authority for black indigeneity and empowerment, upholding Mugabe's populist nationalist ideas about the deserving and authentic 'sons of the soil', and has also been accused of promoting ethnic chauvinism by merging black Zimbabwean nationhood with Shona nationhood (Chitando 2005). The emphasis on the 'sons of the soil' is also used in the diaspora to encourage members to recognise their attachment to Zimbabwe and the need to invest in their homeland. Guti (1997: 43) explains how God commanded him to come back from the usA to Zimbabwe because he was a 'son of the soil'. Guti's theology of black pride fostered a 'patriotic' nationalist narrative of progress (Primorac 2010: 202) in which Talents, reverse mission to the West, and accumulation and re-investment at home are particularly salient. For Guti, blacks can convert and lead the whites, and Africa can be the breadbasket of the West because of her natural resources. But these conversions should be the fruit of diaspora communities who know where their home is, and demonstrate this through their investments back in Zimbabwe.

\section{Idealisations of the Homeland}

Although the meaning of diaspora is contested, it is possible to identify some key features. Return, or the 'myth' of return to the country of origin, is one of the essential characteristics of a diaspora as espoused by classical theorists (Cohen 1997; Safran 1991). Diasporans "regard their ancestral homeland as their true, ideal home and as the place to which they or their descendents

12 Interview Jeff Gadzika, 2/06/2011. 
would (or should) eventually return when conditions are appropriate (...)" (Safran 1991: 83). The life of Guti, his teachings and testimonies about the importance of returning home and supporting the church through tithes are one of the foundations of ZAOGA diasporans' idealisation of their homeland. The interviews and other interactions with ZAOGA members convey this clearly. A zAOGA pastor based in Zimbabwe elaborated the 'home is best' theme in a sermon at the University of Zimbabwe in late 2011:

Home is home, it does not matter what the country is going through; it is just for a season. The situation will change, every country has a season, a season to go through rough times. So I always remind those that I pray for when they want to go out that this is home and they should always remember home. ${ }^{13}$

A church elder with a reputation for preaching against emigration through the slogan 'Diaspora hakuite' ('Diaspora is not oK') explained:

I have never been there but from the testimonies given by our pastors, it is better to stay in Zimbabwe and worship God of Ezekiel freely. Mai Guti and Hildah Bvunzawabaya hid their bibles in a refrigerator [when visiting Saudi Arabia] because if they were found they would be in trouble. We are blessed in Zimbabwe because we have the freedom to worship God and serve Jesus ... it is better we stay and work hard to develop Zimbabwe rather than other countries.

She nonetheless supported congregants who traded across borders, elaborating:

Can't you see that they are just going to buy and come back home. That is what Zimbabweans should do. Ungatiza musha here nokutinyoka yapinda mumba? (Do you abandon the home because a snake has come from the bush? [i.e. imploring Zimbabweans to face challenges at home rather than emigrate]). As long as one remembers to invest at home, that is good. Not just going there to stay for good without remembering those at home or investing at home. ${ }^{14}$

13 Evangelist Chirambadare, Great Hall, University of Zimbabwe, sermon, 22/10/2011.

14 Chengetai Muzanya, 4/04/2011. 
At the same time, ZAOGA pastors jostle for postings abroad to minister to diasporic churches because they are portrayed as places of potential wealth even though they are also cast as foreign and threatening, morally decadent and inferior in comparison to the homeland. Church leaders have to be careful to justify their desire to go abroad in theological terms and not simply as a quest for 'greener pastures'. Any ZAOGA member travelling abroad to the diaspora has to inform both church superiors and congregations, so that they pray for 'journey mercies', because one will be going to 'an unknown land' where there are evil spirits. ${ }^{15}$ Again, the theological reference point is Guti's own experience when he was in the United States. Whilst in Dallas, Guti claims that a white man wanted to lead him astray by offering him large sums of money so that he would not come back to Africa. After prayer, Guti claims that God forbade him to follow the man's instructions because the white man was being used by the Devil. "God said to me, if you follow this man, I will not be with you" (Guti 1997:45). When Guti and his pastors are travelling abroad, the transnational church prays for them not to deviate and succumb to such evil forces. There is also a 24-hour prayer ministry (undertaken especially by single women) for God to protect Guti from evil territorial spirits embedded in particular foreign places (mweya yenzvimbo).

ZAOGA Pentecostals particularise these evil territorial spirits in each specific geographical location in a manner that constantly reproduces an implied negative comparison with Zimbabwe. The growth of transnational connections and diasporic communities can thus nonetheless continue to foster an attachment to an idealised and morally superior homeland through derogatory stereotypes of foreign national cultures derived from the assumption of a dominant national demonic force in each place. "Each country has its own demon", church leaders recounted. ${ }^{16}$

Mozambique, for example, is seen as having the 'demon of poverty'. This is manifest in the frequency of natural disasters and the legacy of the prolonged civil war. A zAOGA evangelist who dislikes Mozambique, but goes when sent for crusades said:

Every country has a demon that operates and controls the lives of people. Look at Mozambique - a country that is very rich but very poor; it has natural resources, but look at the floods that destroy, the suffering of the

15 Personal observations, Harare ZAOGA congregations.

16 Pastor Jeff Gadzika, 02/o6/2011. 
people, the civil war whose effects are still prevalent - that is the demon of poverty in Mozambique! ${ }^{17}$

A female evangelist echoed the sentiments: "there is poverty and many people are suffering - I have been there several times on crusades and I hardly eat. I fear the dirt and disease. I just want to come back home quickly". 18

South Africa, by contrast, is associated by ZAOGA church leaders with the demon of murder and sexual immorality, which manifest in the way people are killed and raped; "South Africans don't value life" is a repeated refrain of my interviewees. ${ }^{19}$ Pastors claim "they [South Africans] do not fear ngozi (avenging spirit); all sorts of evils like rape, theft, ndimo mumusha mazvo (they are deep-seated)". ${ }^{20}$ A student in Pretoria explained:

We have thieves and crooks in Zimbabwe but you cannot compare them with South Africans. In broad daylight they can murder or do anything ... They are loose with their morals ... premarital sexual activities are prevalent even in the church. We need more Forward in Faith churches to transform the people. Most of them are lazy; they do not want to work. Many do not value their bodies as temples of the Holy Spirit. ${ }^{21}$

Returning migrants had tales of abuse and personal experience of violence: "I was abused and cried to the church of Ezekiel in a hostile foreign land" a nurse who had come back from South Africa exclaimed, and now discourages others from going south. ${ }^{22}$ The xenophobic violence against foreign migrants in South Africa in 2008, which affected many Zimbabweans, led to intense prayers within ZAOGA in Zimbabwe for protection against these evil forces, to secure the safety of relatives and friends.

Botswana is also associated by some ZAOGA leaders and members with sexual immorality (though without invocations of criminality), especially in relation to the high rate of HIV/AIDs. Both South Africa and Botswana are condemned for fostering laziness - perhaps a reflection of the fact that so many Zimbabwean migrants are working there. "The Tswana are both lazy and stingy. You can't even pick a pula! (i.e. it is difficult to make money)" a

\footnotetext{
17 Pastor Jeff Gadzika 3/o6/2011.

18 Interview, Pastor Virginia Gadzika, 26/o6/2011.

19 E.g. Regina Zivuku 6/o7/11.

20 Jeff Gadzika, 3/o6/2011.

21 Syvester Mawere 12/02/2012.

22 Patience Mukura 3/05/2011.
} 
Zimbabwean woman working in Botswana exclaimed when back at a ZAOGA service at home. ${ }^{23} \mathrm{~A}$ ZAOGA evangelist and pastor recounted how his teaching in FIFMI in the two countries emphasises a spiritual battle against laziness:

South Africans are lazy. They just want parties. Go there and see most top jobs are occupied by Zimbabweans. It is the same in Botswana; I have pastored there. We have been teaching members of our church to work hard and some are beginning to work. ${ }^{24}$

Malaysia can be imagined as a haven of false religions and immorality and disrespect. A ZAOGA emissary to Malaysia, sent to stop 'the devil snatching the church' reported his experiences of the country and its nationals as such, highlighting their desire to cling to Guti's personal artefacts as evidence:

Malaysians have no morals. The people flock to the pastor's house ... many expect gifts from the pastor. I think it is because ZAOGA has been sponsoring outside churches a lot as the mother church, so to them Zimbabweans are donors. You also have to be careful as a pastor because the ladies can easily trap you ... and sexually provoke you. This was witnessed before when Baba went there and some of the ladies could not even respect him and just sat on Baba's bed. Can you do that here in Zimbabwe to a man of God like Baba? No tine hunhu (we have morals).

We cannot dictate to believers, but we simply have to advise members that they should love their country, stay here and work hard. It is not all roses out there. Do you know that sometimes you 'fast' not because you want to fast but because there is no food to eat? It is my desire to let people know, especially these school leavers, that they should strive to excel here in Zimbabwe, but if God allows them to go, who are we to say no to God? People think of making money and invest at home as Baba teaches us. ${ }^{25}$

Although Guti has generally supported Mugabe's ZANU(PF) government over the years and has repeatedly praised the President for allowing Christians to serve God freely, he has looked unfavourably on some aspects of the 'Look East Policy', for the 'cultural contamination' it threatens. Guti urges his church to pray against the increasing influence of the East within Zimbabwe, especially

\footnotetext{
23 Interview, Violet Mandimuntsira 9/o1/11.

24 Interview, Pastor Jeff Gadzika 26/o6-2011.

25 Pastor Philip Musoni, 27/og/2010.
} 
China because 'they are coming for business opportunities with their heathen gods so believers have to pray to avoid what is happening in other countries where they cannot serve God freely' (Guti 201). More generally, the 'mixing of peoples' provoked through migration can be cast as dangerous: "because the inter-marriages and coming together of different ethnic groups has eroded our Shona morals", Pastor Gadzika explained. ${ }^{26}$ In Pastor Gadzika's primordial understanding of ethnicity, the Shona people are constructed as morally and spiritually superior, and their purity is corrupted by inter-marriages. Such essentialised understandings of a morally superior Zimbabwean nation are upheld partly through derogatory stereotypes of national cultures of the countries into which the church has spread.

Nigeria appears in this array of foreign evil forces as a place of powerful occultism. During the crisis period, connections between Zimbabwe and Nigeria grew dramatically not only through the emergence of a Nigerian business community in downtown Harare but also through connections forged by the church and ZAOGA in particular as individuals made the journey to consult famous Pentecostal religious figures. Many ZAOGA leaders and members have travelled to Nigeria to consult Prophet тв Joshua of the Synagogue Church of All Nations (SCOAN). тв Joshua is a popular Nigerian Pentecostal prophet who is famous for his healing and prophecies. The increase of foreign churches in the city of Harare such as the Nigerian Redeemed Christian Church of God and Angolan Mana churches, among others, poses competition for ZAOGA, contributing to the theological demonisation of foreign cultures and lending moral support to the xenophobic rhetoric and attacks on Nigerian and other foreign businesses in Harare.

Western countries, cast as decadent and in decline, are associated with the 'demon of sexual immorality', the disintegration of families and 'godlessness'. ${ }^{27}$ As Pastor Jeff Gadzika exclaimed to me: "Varungu iganda chete! (The whites are just skin!). They have lost their morals, their soul". ${ }^{28}$ ZAOGA took a leading role in supporting Mugabe's denunciation of homosexuality in 2010 by marching in the streets of Harare (Guti 2011: 85). As one pastor puts it:

Makambozvionepi kuti murume nemurume kana mukadzi nemukadzivanoroorana. Tinotenda vaMugabe vakati kwete muZimbabwe. Ivo varikuenda kunze ava vari kukukutana netsika dzakashata vouya voti ngatitevedzere,

\footnotetext{
26 Pastor Jeff Gadzika, 26/06/2011.

27 Pastor Gadzika, interview 3/o6/2011.

28 Ibid.
} 
saka muno tinoda kumira pakunamata kuti zvakashata zvekunze zvisauye muno (Where did you see men marrying men or women marrying women? We thank Mugabe for saying no to that in Zimbabwe. Those who are going to the diaspora are imitating bad things and they want to influence us here, so we have to pray to avoid all those bad things). ${ }^{29}$

Such stereotypes of foreign countries hosting Zimbabwean diasporic communities are developed partly through comparison to an idealised view of the homeland. It can be argued that the negative portrayal of other countries by Guti and ZAOGA leaders gives legitimacy to the church's evangelisation impetus. Pasura (2013: 206) explains how "diaspora pastors and priests ... use African Christianity and the Ubuntu/Unhu philosophy ... to evaluate their experiences", with constructions of the host land as godless justifying reverse evangelisation (Catto 2008; Pasura 2012). The tendency within ZAOGA/FIFMI to resort to derogatory stereotypes of foreigners has been contested, however, with the argument "We are all people [unhu] - every society has good and bad" being a riposte to the idea that Zimbabwe and Zimbabweans are superior. ${ }^{30}$

In his 2010 letter to all ZAOGA churches in preparation for the annual January Ten Days prayer entitled, 'Tsamba yeMazuva Gumi kuChechi yeZAOGA FIF' (A Letter concerning the Ten Days Prayer for all ZAOGA F.I.F. Churches, Guti 2010), Guti expresses his concern over global migration and the coming together of people of different cultures. As Guti explains, "kusangana kwemarudzi akawanda kunokonzera kuti vanhu varase tsika dzavo nekuita zvivi zvakafanana neupombwe ('the meeting of people of cultures causes our people to lose our good morals and commit sins such as adultery')". Guti portrays Zimbabwe as a Christian nation, regards Zimbabweans as hardworking, and sometimes equates 'Zimbabwean' with 'Shona' provoking accusations of Shona cultural hegemony (Chitando 2005). Some commentators have described Guti as articulating a 'neo-traditional ethos' when he idealises the Shona past (Chitando 2005). Not all that is 'Shona' or 'Zimbabwean' is embraced, however, as ZAOGA disparages witchcraft and encourages its members to maintain a critical distance from the extended family (mweya yemadzinza) on the grounds that working Talents bring material success and provoke jealousy and witchcraft from close relatives which can 'block' the route to riches. My argument here extends Maxwell's (1998, 2001, 2006a) analysis of how Shona imperialism and the disparagement of neighbouring and Western nations have shaped ZAOGA

29 Sermon, Evangelist Chirambadare, 15/09/2011.

$30 \quad$ Interview, Ezekiel Mtetwa, FIFMI Tanzania, 27/07/2011. 
missions through my emphasis on the idealisation of the homeland, the requirement that diasporans invest in Zimbabwe, and reactions to the 'Look East Policy', all of which can deepen our understanding of the essentialised ethnic chauvinism that underpins the movement.

\section{Pilgrimages and Explos}

Pilgrimages often represent a key component of transnational religious life (Wuthnow and Offutt 2008; McLoughlin 2005). They can uphold spiritual centres and also help to maintain boundaries between Christian denominations (Eade and Garbin 2007, 413). The interactions between the globalised ZAOGA/ FIFMI church and the homeland have been shaped through the encouragement of pilgrimages to Zimbabwe. Diaspora members make frequent visits to ZAOGA's sacred places, especially Bindura in Chipinge, the mythical birthplace of ZAOGA, and to Guti's home in the capital city, cottage 593 Highfield, Harare. The cottage, Guti's house before he became a pastor, has become a pilgrimage centre for ZAOGA/FIFMI members, as well as for outsiders in pursuit of spiritual power and renewal. Guti claims to have had divine visitations at these sites including the vision of the second coming of Jesus. By promoting international visits to these places and making it mandatory for ZAOGA/FIFMI leaders to make pilgrimages to them, the church established its transnational nature as well as upholding Zimbabwe as its spiritual home. The annual Deeper Life Conferences at Africa Multination for Christ College in Harare are also important events for ZAOGA and FIFMI. But as the church has expanded, these annual Deeper Life Conferences and other seminars that ZAOGA holds for leadership have been decentralised both in terms of a new provincial structure, in Zimbabwe, and in terms of diasporic centres around the world.

Complementing the 'prosperity gospel', 'deliverance theology' emerged as a key component of African Pentecostalism (Gifford 2004), which is reflected within ZAOGA/FIFMI by deliverance crusades known as 'Explos'. These are events that seek to deliver participants from demons and evil spirits. ZAOGA promotes a belief in witches and witchcraft activities, upholding the idea that there is always a causative agent, either good or bad, for any event. This gives a prominent place to deliverance 'Explos', in which church members can be freed from the forces of witchcraft, which are equated with Satanic forces/demons. Eunor Guti (the wife of Ezekiel Guti) initiated the idea of 'Explos' in 2005, justifying them by the idea that there is a need to deliver people from the 'blockade' caused by the devil. 'Explos' are similar to 'crusades' but the ZAOGA leadership have branded them afresh to enhance their appeal. 'Explos' have 
increased the interaction between ZAOGA and diasporan communities. The justification for Explos abroad can reinforce the negative national stereotyping detailed above - as one of my interviewees who lived in Malawi but had built a house and supported family in Shurugwi, Zimbabwe elaborated: "Malawians are expert witches; I am afraid of them. I live in fear - we need Explos because of that".31

The growing influence of transnational connections, means that the issues dealt with in these Explos also regularly touch on matters of migration, intersecting with longer-standing concerns over troubling family relationships, work and the ubiquitous battle against witchcraft and evil. For example, visas for foreign travel are infused with ZAOGA's spiritualised logic. In Harare, the church prays for Guti and church pastors to be blessed with travel documents. Because travel visas and rights to work abroad are problematic to obtain with a Zimbabwean passport, these issues were frequently brought up in interviews. People who faced problems in getting visas, who were deported or returned home empty handed for other reasons interpreted their ill fate as acts of witchcraft on the part of relatives. Fiona Chinakidzwa was deported from the USA where she had been studying and had run a business with fellow Zimbabweans and explained:

It's painful but God is faithful. Do you know that he (God) had spoken to me before I went to America. Firstly he said, "No one goes on a journey and comes back home empty handed". Secondly he told me about witchcraft activities and I thought that there are no witches in America. I did not understand at that time that my fellow Zimbabweans were the ones that were to be jealous of me, and also bewitch me, although I know that in my family there are people who also cast spells and want to see us suffering. ${ }^{32}$

Now, Fiona was trying to get a visa for the UK, and had sought blessing from ZAOGA. Precious Samanga elaborated how a woman who had been deported had blamed her expulsion as a result of jealousy, and had sought deliverance through the church. ${ }^{33}$ Relatives' jealousy, she claimed, had caused the apparition of a baby on the woman's back when there was none, which had resulted in her removal by officials:

\footnotetext{
31 Grace Tavengwa, 24/05/11.

32 Interview 19/1/2011.

33 Interview, Precious Samanga 23/o8/2009.
} 
I know someone who was deported at Heathrow. The officials asked her the particulars of the baby that she was carrying at her back. Yet, in fact, she had no baby on her back. She insisted that she had no baby, but she was deported. This is witchcraft - jealous relatives cast a spell. ${ }^{34}$

The failure of her migration project was thus cast as a spiritual problem caused by evil spirits and witchcraft emanating from within the extended family. Jealousy among colleagues in the diaspora, was frequently raised by interviewees, who felt it confirmed Guti's teachings that instead of demonstrating love to one another, Zimbabweans in the diaspora were jealous of each other. ${ }^{35}$ It was also upheld as evidence of the power of the foreign territorial spirits, of the need for visits from ZAOGA leaders and for Deliverance Explos.

Another significant theme discussed during 'Explos' is the widespread breakdown of marriages as a consequence of international migration (Pasura 2008; Kufakurinani et al. 2014). ZAOGA is tough on divorce, which its pastors preach against, upholding the importance of preserving families. In 2007, Guti founded the Families Builder Ministry (FAMB) as a church organisation to control the breakdown of marriages and disintegration of families. ${ }^{36}$ (FAMB Letter to ZAOGA Churches 2011). The timing of this 2007 initiative is significant as it corresponds with the peak of the economic crisis and mass survival emigration. Guti teaches that families should stay together in order to avoid the temptation of fornication or adultery, and male pastors and evangelists have to travel with their wives. If factors militate against married people migrating as a couple, FAMB discourages their departure in line with its aim to build strong families, restore broken families and preserve 'our values'. The FAMB also discourages men working in town from leaving wives behind in the rural areas, teaching that husbands should stay with them in cities rather than provoking divorces like those in the diaspora (Guti 2011). ${ }^{37}$

\section{New Media and Language: Ezekiel TV}

The development of new media has facilitated the intensification of exchanges between the homeland church and its external congregations. Ezekiel TV -

34 Ibid.

35 For an explanation of diasporic fractiousness and an elaboration of the conflicts, tensions and suspicions that mark diasporic social and political life, see McGregor (2010).

36 Detailed in ZaOga FAMB Letter, 2011.

37 See also ZAOGA FAMB Letter 2011. 
ZAOGA/FIFMI's television channel established in 2005 - enables the leadership to become media personalities. It promotes Guti's celebrity status within his 'religious empire' and at the same time links diasporan communities with those at home. The Church has an interactive website and numerous Facebook pages. This has helped Guti become a living saint', in a similar way to the Nigerian Pentecostal church leaders described by Achunike (2004:11) and Marshall-Fratani (1998).

All ZAOGA/FIFMI members are encouraged to subscribe to Ezekiel TV. This involves paying uS $\$ 2$ a month, including on behalf of others, in order to receive daily messages of prayer. A ZAOGA elder announced to the congregation in Harare's relatively affluent suburb of Marlborough, for example, that each member should pay this amount to receive devotional prayers/messages themselves and they were told that they could also subscribe on behalf of friends and relatives. ${ }^{38}$ Ezekiel TV subscriptions are thus a way of raising money for the ministry in Zimbabwe as well as abroad and the messages that it beams daily into homes also provide reminders of the church's global reach as a variety of languages are used in the broadcast services, prayers and hymns. ZAOGA incorporates different languages from the places where FIFMI is established and these have an impact on congregations at home who are subscribers. Praise and worship, especially in urban centres within Zimbabwe, use a range of languages alongside Shona and English, with songs sung in African languages from across the southern part of the continent in particular Nyanja, Tonga, Venda, Sotho and Tswana. This is very attractive especially to the youth, who like the sense of transnational connection and influence. Such innovation is a source of considerable vitality for the church and is evidence of the creative way external influences and strategies are domesticated and made to perform a range of purposes both within the diaspora and for local homeland congregations. Focusing on growing Christian charismatic and Pentecostal movements in Ghana and Nigeria and exploring the rationale behind their appropriation of electronic media as sites for the dissemination of their teachings, Hackett (1998: 258) sees it as "a tool of expansion, a reflection of globalizing aspirations, but it is also part of a calculated attempt to transform and Christianize popular culture so that it is safe for consumption by 'born-again' Christians".

38 Personal observation December 2011, Marlborough, Harare. 


\section{Conclusion}

The article demonstrated how the life and experiences of Ezekiel Guti in Dallas have been invoked in ZAOGA's theology, influencing congregants' attitudes towards migration and shaping the configuration of transnational religious connections with the homeland. Although ZAOGA's transnational expansion predated the Zimbabwe crisis (Maxwell 2006a), the article expands earlier scholarship on ZAOGA (Maxwell 2006, Chitando 2005) by examining how transnational ties, strengthened through the phenomenal exodus from 2000, have significantly affected the church's teaching and practice in a number of ways. First, it argued that the migration of Zimbabweans abroad is constructed as temporary and an opportunity not only to evangelise but also to invest at home. Second, it highlighted the role of new media and diversification of languages used within the homeland church: ZAOGA/FIFMI seeks to create and sustain transnational religious identities and communities beyond familial, ethnic and national boundaries, and broadcasts through Ezekiel TV use diverse languages, to heighten the church's international feel and popularise its global reach. Third, it extended understandings of how the church can also propagate essentialised notions of ethno-racial or national cultural difference and foster chauvinism, by providing new evidence of ZAOGA's modes of idealising the Zimbabwean homeland, and its landscape of sacred religious pilgrimage sites. This is reinforced by the way ZAOGA casts its presence elsewhere as embattled against enemy territorial spirits that encapsulate essential elements of national character, fostering denigrating stereotypes of foreign places and foreigners. Corten and Marshall-Fratani (2001: 1) capture this capacity to both cross and erect boundaries simultaneously, describing how contemporary Pentecostalism is the "most striking example of the paradox of difference and uniformity, flow and closure, that seems to be at the heart of the processes of transnationalism and globalisation". As diaspora members make pilgrimage visits to ZAOGA's sacred places and embark on Explos, the church both establishes its transnational nature and upholds Zimbabwe as its spiritual home.

As transnational connections have grown in different global destinations over the crisis decade, the negative portrayal of other countries' spiritual battles with evil forces through ZAOGA/FIFMI leaders' teaching gives legitimacy to the church's evangelisation. The expansion of Pentecostal Christianity is the product of such missionary work, but has been given huge momentum through African emigrations for work and other reasons, leading to the proliferation of African Pentecostal Christian congregations in Europe that are changing the face of Christianity on the continent (Adogame 2013; Catto 2008; Pasura 2012). ZAOGA's encouragement of temporary emigration through its teaching was a 
particular feature of the last decade, when movement beyond Zimbabwe's borders was so necessary for the basic survival of the family at home as well as constituting an important source of revenue for the church. But after the formation of the Government of National Unity in early 2009 and the economic stabilisation that followed the withdrawal of the Zimbabwe Dollar in favour of the Us Dollar, church leaders' teaching on the morality of mobility has begun to shift. Some pastors have begun modifying their spiritual message and are now teaching that only those who are convinced that God has spoken to them should emigrate because the situation is improving in Zimbabwe. Their spiritualised support for emigration was pinned to a temporary understanding of mobility and mission, and to a diasporic consciousness that emphasised the morality of work, accumulation and investment in an idealised homeland.

\section{References}

Achunike, H. 2004. The challenges of pentecostalism to the mainline churches in Nigeria, Koinonia, 2(1): 4-16.

Adogame, Afe. 2008. 'Up, up Jesus! Down, down satan'! African religiosity in the former Soviet Bloc the Embassy of the Blessed Kingdom of God for All Nations. Exchange 37(3): $310-336$.

Adogame, Afe. 2009. Ranks and robes: Art symbolism and identity in the Celestial Church of Christ in the European diaspora. Material Religion, 5(1): 10-32.

Adogame, Afe. 2013. The African Christian diaspora: New currents and emerging trends in World Christianity. London: Bloomsbury Academic.

Anderson, Allan. 2004. An introduction to Pentecostalism: Global Charismatic Christianity Cambridge: Cambridge University Press.

Catto, Rebecca Alice. 2008. From the rest to the West: Exploring reversal in Christian Mission in Twenty-First century Britain. Unpublished PhD Thesis, University of Exeter, UK.

Chitando, Ezra. 2005. 'In the beginning was the land': The appropriation of religious themes in political discourses in Zimbabwe. Africa 75(2): 220-239.

Cohen, Robin. 1997. Global diasporas: An introduction. London: University College London Press.

Corten, Andrae and Ruth Marshall-Fratani. 2001. Introduction. In: Andrae Corten and Ruth Marshall-Fratani (eds), Between Babel and Pentecost: Transnational Pentecostalism in Africa and Latin America. Bloomington; Indianapolis: Indiana University Press.

Crush, Jonathan and Daniel Tevera. 2010. Zimbabwe's exodus, crisis, migration, survival. Kingston and Cape Town: SAMP. 
Dijk, Rijk van. 1997. From camp to encompassment: Discourses of transsubjectivity in the Ghanaian Pentecostal diaspora. Journal of Religion in Africa 27(2): 135-159.

Dijk, Rijk van. 2002. The soul is the stranger: Ghanaian Pentecostalism and the diasporic contestation of "flow" and "individuality". Culture and Religion 3(1): 49-65.

Eade, John and David Garbin. 2007. Reinterpreting the Relationship between Centre and Periphery: Pilgrimage and Sacred Spatialisation among Polish and Congolese Communities in Britain. Mobilities 2 (3): 413-424.

Englund, Harri. 2007. Witchcraft and the limits of mass mediation in Malawi. Journal of the Royal Anthropological Institute 13(2): 295-311.

Fumanti, Mattia. 2010. Virtuous citizenship: Ethnicity and encapsulation among AkanSpeaking Ghanaian methodists in London. African Diaspora 3(1): 12-41.

Gifford, Paul. 1988. The religious right in Southern Africa. Harare: Baobab Books.

Gifford, Paul. 2004. Persistence and Change in Contemporary African Religion. Social Compass 51 (2): 169-176.

Guti, E. 1997. History of ZAOGA forward in faith. The book of remembrance. Harare, EGEA Publications.

Guti, E. 2010. Ten Days Letters to ZAOGA and FIFMI Churches.

Guti, E. 2011. School of Prophecy. Harare, EgEA Publications.

Hackett, Rosalind I.J. 1998. Charismatic/Pentecostal appropriation of media technologies in Nigeria and Ghana. Journal of Religion in Africa 28(3): 258-277.

Hinnells, John R. 1997. A new handbook of living religions. London: Penguin.

Hunt, Stephen. 2002. 'Neither here nor there': The construction of identities and boundary maintenance of West African Pentecostals. Sociology 36(1): 147-169.

Kalu, Ogbu. 2008. African Pentecostalism: An introduction. Oxford: Oxford University Press.

Koning, Danielle. 2009. Place, space, and authority. The mission and reversed mission of the Ghanaian Seventh-Day Adventist Church in Amsterdam. African Diaspora 2(2): 203-226.

Kufakurinani, Ushehwedu, Dominic Pasura and JoAnn McGregor. 2014. Transnational parenting and the emergence of 'diaspora orphans' in Zimbabwe, African Diaspora 7(1): 114-138.

Levitt, Peggy. 1998. Local-level global religion: The case of U.s.-Dominican migration. Journal for the Scientific Study of Religion 37(1): 74-89.

Levitt, Peggy. 2008. Religion as a path to civic engagement. Ethnic and Racial Studies 31(4): 766-791.

Levitt, Peggy and Nadya Jaworsky. 2007. Transnational migration studies: Past developments and future trends. Annual Review of Sociology 33(1): 129-156.

Mahler, Sarah J. and Katrin Hansing. 2005. Toward a transnationalism of the middle: How transnational religious practices help bridge the divides between Cuba and Miami. Latin American Perspectives 32(1): 121-146. 
Marshall-Fratani, Ruth. 1998. Mediating the global and local in Nigerian Pentecostalism. Journal of Religion in Africa 28(3): $278-315$.

Maxwell, David. 1998. 'Delivered from the spirit of poverty?': Pentecostalism, prosperity and modernity in Zimbabwe. Journal of Religion in Africa 28(3): 350-373.

Maxwell, David. 2001. Sacred history, social history: Traditions and texts in the making of a Southern African transnational religious movement. Comparative Studies in Society and History 43(3): 502-524.

Maxwell, David. 2006a. African gifts of the spirit: Pentecostalism \& the rise of a Zimbabwean transnational religious movement. Harare, Weaver Press.

Maxwell, David. 2006b. Writing the history of African Christianity: Reflections of an editor, Journal of Religion in Africa 36: 379-399.

McGregor, JoAnn. 2010. The making of Zimbabwe's new diaspora. In: JoAnn McGregor and Ranka Primorac (eds) Zimbabwe's new diaspora. Displacement and the cultural politics of survival. New York: Berghahn Books.

McGregor, JoAnn and Ranca Primorac. 2010. Zimbabwe's new diaspora. Displacement and the cultural politics of survival. New York: Berghahn Books.

McLoughlin, Sean. 2005. Migration, diaspora and rransnationalism: Transformations of religion and culture in a globalising age. In: John R. Hinnells (ed), The routledge companion to the study of religion. London: Routledge.

Menjivar, Cecilia. 1999. Religious institutions and transnationalism: A case study of Catholic and Evangelical Salvadoran immigrants. International Journal of Politics, Culture \& Society $12(4): 589-612$.

Meyer, Birgit. 1998. 'Make a complete break with the past'. Memory and post-colonial modernity in Ghanaian Pentecostalist discourse, Journal of Religion in Africa 28(3): 316-349.

Pasura, Dominic. 2008. Gendering the Diaspora: Zimbabwean Migrants in Britain. African Diaspora 1-2: 86-109.

Pasura, Dominic. 2012. Religious transnationalism: The case of Zimbabwean Catholics in Britain. Journal of Religion in Africa 42(1): 26-53.

Pasura, Dominic. 2013. Modes of incorporation and transnational Zimbabwean migration to Britain. Ethnic and Racial Studies 36(1): 199-218.

Pasura, Dominic. 2014. African transnational diasporas: Fractured communities and plural identities of Zimbabweans in Britain. Basingstoke: Palgrave Macmillan.

Primorac, Ranka. 2010. Rhodesians never die? The Zimbabwean crisis and the revival of Rhodesian discourse. In:JoAnn McGregor and Ranka Primorac (eds), Zimbabwe's new diaspora: Displacement and the cultural politics of survival. New York: Berghahn Books.

Ralph, Grillo. 2004. Islam and transnationalism. Journal of Ethnic and Migration Studies 30: $861-878$.

Robbins, Joel. 2003. On the paradoxes of global Pentecostalism and the perils of continuity thinking. Religion 33(3): 221-231. 
Safran, William. 1991. Diasporas in modern societies: Myths of homeland and return. Diaspora 1(1): 83-99.

Ter Haar, Gerrie. 1998. Halfway to paradise: African Christians in Europe. Cardiff: Cardiff Academic Press.

Wuthnow, Robert and Stephen Offutt. 2008. Transnational religious connections. Sociology of Religion 69(2): 209-232. 